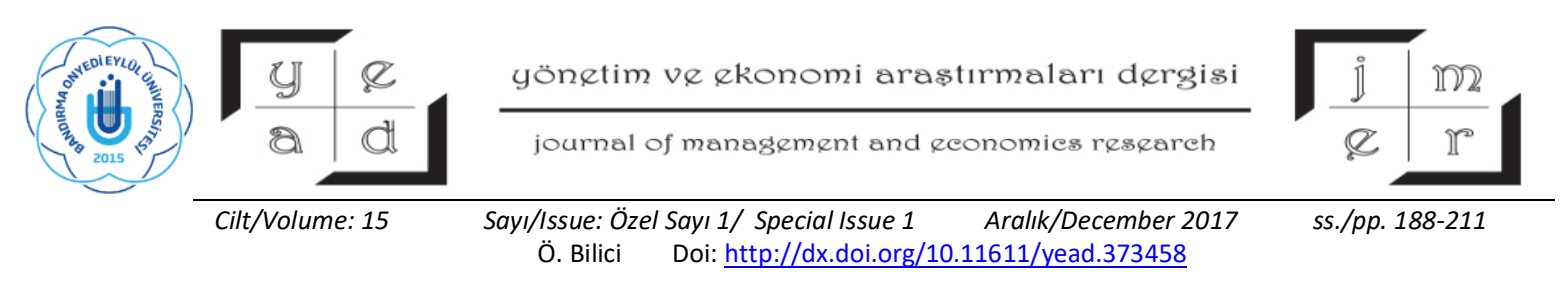

\title{
MACRO AND MICRO DETERMINANTS OF TRADE IN SERVICES: THE CASE OF BRITISH SERVICE TRADERS ${ }^{12}$
}

\section{Asst. Prof. Özgül BİLící ${ }^{*}$}

\begin{abstract}
This paper focuses on the macro and micro-level determinants of trade in services in the United Kingdom. The importance of different determinants has been investigated within the gravity framework in many studies. However, the nature of the data requires estimation approaches other than the Ordinary Least Squares (OLS). To estimate the gravity equation, besides the OLS, the Poisson PseudoMaximum Likelihood (PPML) and Threshold Tobit have been used. The results confirm that, among the three different estimation approaches, the PPML is the preferred model since it is able to deal with the existence of zero trade values and heteroskedaticity problem in the data. The findings based on the disaggregated level data show that the coefficients of the trade determinants change considerably, suggesting that the policies adopted according to the results of the country-level analyses do not fit all of the trading firms.
\end{abstract}

Keywords: Services Trade, Trading Firms, Gravity Equation, Tobit, PPML

JEL Classification: F10, F14, F23

\section{HIZMET TICARETININ MAKRO VE MIKRO BELIRLEYENLERİ: İNGILIZZ FİRMALARI ÜZERİNE BİR CALIŞMA}

ÖZ

Bu çalışma İngiltere'nin hizmet ticaretinin makro ve mikro belirleyenleri analiz etmektedir. Ticareti belirleyen etmenlerin önemi, uzun zamandır çekim modeli çerçevesinde incelenmektedir.

\footnotetext{
${ }^{1}$ A detailed version of this paper constitutes the first chapter of my $\mathrm{PhD}$ thesis. I would like to express my deepest appreciation to my supervisor Professor Holger Breinlich for his excellent supervision throughout my studies. I am also thankful to Professor João Santos Silva and Dr. Gregory Wright who contributed to this work with their valuable comments. This work was based on data from the International Trade in Services Survey, Annual Respondents Database and Business Structure Database, produced by the Office for National Statistics (ONS) and supplied by the Secure Data Service at the UK Data Archive. The data are Crown Copyright and reproduced with the permission of the controller of HMSO and Queen's Printer for Scotland. The use of the data in this work does not imply the endorsement of ONS or the Secure Data Service at the UK Data Archive in relation to the interpretation or analysis of the data. This work uses research datasets which may not exactly reproduce National Statistics aggregates. All errors are mine.

2 This paper is presented is at ICOAEF 2017 conferance on 06-07 December 2017.

* Recep Tayyip Erdoğan University, email: ozgul.bilici@erdogan.edu.tr
} 
Yönetim ve Ekonomi Araștırmaları Dergisi / Journal of Management and Economics Research Cilt/Volume: 15 Sayı/Issue: Özel Sayı 1/Special Issue 1 Aralık/December 2017 ss./pp. 188-211 Ö. Bilici Doi: http://dx.doi.org/10.11611/yead.373458

Ancak ticaret verisi doğası gereği En Küçük Kareler (EKK) tahmin yönteminden başka tahmin yöntemlerini gerektirmektedir. Bu çalışmada, Ingiltere'nin firma düzeyinde hizmet ticaretinin belirleyenlerini tahmin etmek için EKK'nin yanında PPML ve Tobit yöntemi kullanılmıştır. Sonuçlar, kullanılan üç tahmin yöntemi içinde en iyi performansı PPML yönteminin gösterdiğini saptamıştır. Bu yöntem, verideki sıfirları ve değişen varyans problemini dikkate almaktadır. Firma verileri dikkate alınarak yapılan analizler, her bir ticaret belirleyeninin katsayısının, ülke düzeyinde yapılan analizlerden farklılık gösterdiğini saptamıştır. Bu da ülke düzeyinde analizleri dikkate alarak yapılan politika önerilerinin ticaret yapan her bir firma için uygun olmayacağını göstermektedir.

Anahtar Kelimeler: Hizmet Ticareti, Firma Ticareti, Çekim Modeli, Tobit, PPML

Jel Sinıflandırması: F10, F14, F23

\section{INTRODUCTION}

The importance of international trade in services has increased during the last two decades all over the world. It has demonstrated faster growth than goods trade. According to World Trade Organization (WTO) statistics, world exports in commercial services (services excluding governmental services) stood at 3.7 billion USD in 2010 with an average annual growth rate of more than $15 \%$ over the past 20 years. Its share in total world exports was around $20 \%$ while its share in GDP was roughly $12 \%$. Moreover, World Development Indicators produced by World Bank showed that nearly $71 \%$ of global value added in 2010 was generated in the services sector, with a 3\% average annual growth rate from 1990 to 2010, while the services sector also accounts for around 45\% of total employment.

Due to the increasing economic importance of trade in services within the economy, researchers have started to pay more attention to trade in services and its policy implications. Many aspects of trade in services have been analysed. Since services are very heterogeneous across a wide range of economic activities, it is difficult to capture the impact of services trade on economic growth and development. Most studies mostly focus on the similarities and differences between goods trade and services trade (Lennon, 2009; Breinlich and Criscuolo, 2011), the importance of distance for trade in services (Bhagwati, 1984; Amiti and Wei, 2005), the relationship between and relative importance of different modes of services trade (Lennon, 2009; Christen and Francois, 2010) and the effects of market structure, regulations and trade policies on services trade (Deardorff, 2001; Francois and Wooton, 2001). Moreover, the empirical framework of the gravity equation has been used to explain the determinants of service trade flows at country-level (Mirza and Nicoletti, 2004; Kimura and Lee, 2006; Head et al, 
Yönetim ve Ekonomi Araștırmaları Dergisi / Journal of Management and Economics Research Cilt/Volume: 15 Sayı/Issue: Özel Sayı 1/Special Issue 1 Aralık/December 2017 ss./pp. 188-211 Ö. Bilici Doi: http://dx.doi.org/10.11611/yead.373458

$2009)^{3}$. More recently, thanks to the increasing availability of micro data, firm-level datasets have been used to investigate the characteristics of the exporters and importers of services and the concentration of trade across firms; and to compare service traders and non-service traders with respect to productivity, wages, size, turnover and differentiation level (Breinlich and Criscuolo, 2011; Kelle and Kleinert, 2010; Federico and Tosti, 2012). However, within the literature, there are only a few studies which apply the gravity framework to explain firm-level determinants of service trade flows (McCann and Toubal, 2011; Ariu, 2010; Federico and Tosti, 2012). These studies focus on the effects of distance on margins of trade and does not take into account the effects of differences between countries along with firm-level factors. However, these studies only focus on the effects of distance on margins of trade and does not take into account the effects of differences between countries along with firm-level factors. Therefore, we still only have a limited understanding of which forces govern services trade at the firmlevel. Given that the effects of variables such as distance, cultural differences, or regulatory and policy barriers to services trade are likely to vary considerably between different types of firms, it is important to undertake more research in this area in order to better understand aggregate level trade flows as well. For example, if certain types of trade barriers are particularly important for more innovative firms, export promotion programs could be specifically targeted to help this group of firms.

Having identified this deficiency in the existing literature, the aim of this study is to investigate the validity of the gravity model for trade in services in the UK, taking into account both country- and firm-level factors, and to analyse the importance of different determinants within this framework. The UK has been chosen for the analyses because it is among the largest service traders in the world (the third largest exporter and fourth largest importer in commercial services according to WTO (2011)) and the UK Office for National Statistics (ONS) provides a very-well established database of firm-level data.

To the best of our knowledge, this study is the first study which applies the gravity equation to a firm-level data and comprehensively investigates determinants of firm-level services trade. The newly constructed data on the UK firm-level services trade produced by the ONS facilitates this research since it provides a wide range of variables related to almost all producer services traders in the UK. Another novel feature of this study involves the methodology that is used in the analyses. In order to examine how the effects of different determinants of firm-level services trade (e.g. distance or GDP) may differ from country and industry-level analyses, we use three estimation approaches to estimate the gravity equation, namely Ordinary Least Squares (OLS), the Tobit and the Poisson Pseudo-Maximum Likelihood (PPML). This is the first study that applies PPML to estimate determinants of firm-level

\footnotetext{
3 See also (Francois, 1993; Grunfeld and Moxnes, 2003; Francois and Hoekman, 2010; Tharakan et al, 2005; Kandilov and Grennes, 2010, 2012; Freund and Weinhold, 2002; Walsh, 2006).
} 
Yönetim ve Ekonomi Araștırmaları Dergisi / Journal of Management and Economics Research Cilt/Volume: 15 Sayı/Issue: Özel Sayı 1/Special Issue 1 Aralık/December 2017 ss./pp. 188-211 Ö. Bilici Doi: http://dx.doi.org/10.11611/yead.373458

services trade. The nature of the data (the existence of zero trade flows between some firms and some countries in some service types) makes the implications of PPML both reasonable and interesting. The results show that the gravity equation is also successful in explaining the determinants of firm-level services trade and the RESET test results confirm that, among three different estimation approaches, the PPML is the preferred model since it is able to deal with the existence of zero trade values and heteroskedaticity problem in the data. Another good property that PPML holds is arisen when we compare the results obtained from firm-level analyses with the ones obtained from country-level analyses. The coefficients obtained from the OLS estimations are considerably different from each other while PPML provides the similar results in both firm-level and country-level analyses. Since for the PPML estimations, it is not necessary to take the log of dependent variable, the coefficients do not change by changing the level of aggregation. The PPML results suggest that there is no additional benefit of collapsing data down to firm-level. This finding is of great importance when the policy makers utilize a policy based on the empirical studies. The policy implications based on the OLS results from country-level data would be misleading since these results are considerably different from the ones obtained from firm-level data.

The rest of the paper is organized as follows Section 2 provides information on the databases and a description of the variables while the methodology used is presented in Section 3. Section 4 provide the analysis results obtained from empirical models, and Section 5 concludes.

\section{DATA}

This study considers both country- and firm-level factors in order to detect the heterogeneous impacts of different variables on the firm-level services trade in a gravity framework. To this end, several data sources are used. The main data sources are the survey-based limited access data on the UK private sector companies conducted by the ONS. Each survey contains Inter-Departmental Business Register (IDBR) reference numbers which are anonymous but unique reference numbers assigned to the business organizations. This allows us to combine different surveys.

The main data source used in this study is the UK's International Trade in Services Inquiry (ITIS). ITIS data is collected from a number of different surveys and administrative sources and it covers the period 1996-2005. The sample size of the survey is roughly 20,000 firms (from 2001 onwards, prior to which it was approximately 10,000). However, when the firms which report international transactions are considered, the data provides service exports and imports figures of around 5,000 firms for 46 different types of services classified by country of origin and destination for over the period 1996-2005. The companies with over 10 employees have been included in the inquiry. 
Yönetim ve Ekonomi Araștırmaları Dergisi / Journal of Management and Economics Research Cilt/Volume: 15 Sayı/Issue: Özel Sayı 1/Special Issue 1 Aralık/December 2017 ss./pp. 188-211 Ö. Bilici Doi: http://dx.doi.org/10.11611/yead.373458

ITIS provides information on producer services and excludes travel and transport, some banking, financial and legal services, higher education and film and television companies. Since the highest number of firms was covered in 2005, this study focuses on the data from 2005 only ${ }^{4}$.

The Annual Respondent Database (ARD) and the Business Structure Database (BSD) are the other micro data sources which provide firm specific variables. The ARD provides structural variables for firms and is constructed from a compulsory business survey which is based on the Annual Business Inquiry (ABI) from 1998 onwards. The data encompasses many variables such as employment, turnover/output, capital expenditure, intermediate consumption, gross value added (derived), postcodes, industrial classification, owner nationality, acquisitions and disposals of capital goods for both smaller and larger businesses (depending on the year, firms with more than 100 or 250 employees). To control for firm specific characteristics, variables for firm size, productivity and research and development (R\&D) engagement, which are obtained from the ARD, have been used in the analyses. The firm size and productivity of firms are measured by the variables of employment and gross value added per employee, respectively. The $R \& D$ variable is an indicator variable that shows whether a firm engaged in research and development work on a regular basis during the year in question. Depending on this indicator, we create a dummy variable which takes the value of 1 if a firm is engaged in R\&D work. Other firm characteristics such as firm age and legal status are obtained from the BSD. The BSD contains a small number of variables for almost all business organisations in the UK for the period 1997-2010 in order to reflect a wide variety of firm demographics. The firm age variable is calculated by using the birth date and active variables. If the firm was active in 2005 then we subtracted their year of birth from 2005. Lastly, we create an LLC dummy using the legal status of a firm variable as a measure of the extent to which business operations were financed by external sources. The dummy takes the value of 1 if a trading firm is an LLC and 0 otherwise. All firm-level variables except firm age are expected to have a positive impact on firm-level exports and imports.

The last data source that is used in this study is the CEPII Gravity Database. This is a freely available dataset generated by Head et al (2010). In order to analyse the country- and firm-level determinants of trade in services for the UK using the gravity equation, data sources providing countrylevel data are combined with the firm-level datasets given above. All country-level variables except dummy variables for European Union (EU) membership (GDP and GDP per capita of the trading partner; distance and time differences between the countries; dummies for colonial relationship; common language; common legislation; regional trade agreement; and GATT (WTO) membership) are obtained from the CEPII Gravity database. The information on the EU membership has been obtained

\footnotetext{
${ }^{4}$ An updated version of the data has been released by the ONS in 2014, but at the time of research it was not accessible yet.
} 
Yönetim ve Ekonomi Arastırmaları Dergisi / Journal of Management and Economics Research Cilt/Volume: 15 Sayı/Issue: Özel Sayı 1/Special Issue 1 Aralı/December 2017 ss./pp. 188-211 Ö. Bilici Doi: http://dx.doi.org/10.11611/yead.373458

from European Commission webpage. After merging the gravity data with the aforementioned firmlevel data, we obtained exports and imports datasets: 1,754 firms exporting to 181 countries in 46 service types and 1,909 firms importing from 177 countries in 46 service types. However, the ITIS only reports observation with positive transaction values. If a firm does not import from or export to a particular country in a particular service type, it is excluded from the ITIS. Therefore, we enlarged the data using observations with zero trade values. After obtaining rectangularized data, there are around 15 million observations in each dataset.

Since we combine country-level data with firm-level data in order to investigate the effects of country characteristics on firm-level exports and imports, in order to obtain true inferences, the random disturbances should be independent within the groups. If the disturbances are correlated within the groups (in our case, countries) that are used to merge firm-level data with country-level data, then even small levels of correlation can cause poor inference because of the downward biased standard errors (Moulton, 1990). In the case of within-group correlation, cluster corrected standard errors can be used to improve the inference (Angrist and Pischke, 2009). In our case, the main explanatory variables of interest vary only at country-level. It is expected that firms trading with a certain country might share some unobservable characteristics which would lead the regression disturbances to be correlated. Therefore country-cluster corrected standard errors are used in all the models.

\section{METHODOLOGY}

Following the pioneering studies by Timbergen (1962) and Poyhonen (1963), the gravity model has been used as an empirical tool in this study. It is one of the most widely used models in international trade due to its simplicity. It fits the available data well and makes it easy to obtain econometric estimations. The model explains bilateral trade flows between any two countries as a function of their economic size and the distance between them. The most commonly used definition of the gravity equation is the standard form of the gravity equation which estimates bilateral trade proportional to the products of country sizes:

$$
T_{o d}=\beta_{0} \frac{Y_{o}^{\beta_{1}} Y_{d}^{\beta_{2}}}{D_{o d}^{\beta_{3}}}
$$

where $T_{o d}$ is the trade flow from the origin country to the destination country. $Y_{o}$ and $Y_{d}$ are the economic sizes of the origin and the destination countries, mostly measured by GDP. $D_{o d}$ is the proxy for transaction cost measured by the geographical distance between countries. Lastly, $\beta_{0}$ is termed as the 'gravitational constant'. Starting from Timbergen (1962), this equation has been used in a number of studies to explain trade flows. $\beta_{1} \neq \beta_{2} \neq 1$ is assumed in preceding studies. However, most theories 
Yönetim ve Ekonomi Araștırmaları Dergisi / Journal of Management and Economics Research Cilt/Volume: 15 Sayı/Issue: Özel Sayı 1/Special Issue 1 Aralık/December 2017 ss./pp. 188-211 Ö. Bilici Doi: http://dx.doi.org/10.11611/yead.373458

predict unit elasticity for GDP. Another restriction of this definition is that $D_{o d}$ is assumed to be constant, which means that the effects of different trade costs incurred by each country are overlooked (Head and Mayer, 2013).

In this study, an augmented version of the gravity equation has been used, which has been adapted to the firm-level data. The augmented gravity equation is given below:

$$
T_{i d s}=A_{d}^{\alpha} B_{i}^{\beta} \exp \left(Z^{\prime} \gamma+\epsilon_{i d s}\right)
$$

where $T_{i d s}$ denotes export (import) flows by firm $i$ to (from) the destination (the origin) country $d$ in service type $s$. There are two sets of explanatory variables on the right-hand side. $A_{d}$ contains countrylevel variables, such as GDP of trading partner, bilateral distance and time differences, whereas variables related to the firm characteristics such as firm size and productivity are included in the set $B_{i}{ }^{5}$. $Z$ denotes the vector of other control variables including firm and/or service type fixed effects and dummies such as common language and $\mathrm{R} \& \mathrm{D}$ engagement. $\epsilon_{i d s}$ is the error term from this multiplicative form. The variable list, their sources and the expected sign of all the explanatory variables are given in Table 1.

Following the existing literature, first, the log-linearized form of equation 2 is estimated by OLS using the original data which reports only the positive trade values. Then we enlarge the dataset with the zero trade values. However, the existence of zeros in trade flows makes the OLS result to become biased since zero values are omitted when taking the logarithms. To overcome this problem we use two alternative methods. The first approach is the Threshold Tobit estimation proposed by Eaton and Tamura (1994). It overcomes the problem of zero values; however, its consistency depends on the normal distribution assumption ${ }^{6}$. Although the Tobit model allows us to obtain estimates in the case of zero trade flows, it adopts the linear specification, similarly to OLS, and therefore it is subject to heteroskedasticity due to Jensen's inequality, as pointed out by Silva and Tenreyro (2006). According to Silva and Tenreyro (2006), the OLS estimator is not only biased but also inconsistent because the error term in the model depends on the regressors due to heteroskedasticity in multiplicative form. Therefore, as the second approach the PPML is used. It is a consistent estimator under the correct specification of the conditional mean of the dependent variable as well as being able to deal with zero trade flows. There are few studies that estimate the gravity equation using the PPML approach (Silva

\footnotetext{
${ }^{5}$ The logarithms of all variables except dummies and time differences between countries are taken in line with the gravity framework.

${ }^{6}$ The comparison of coefficients from the OLS and the Tobit is not very informative, since in the Tobit model, the linear effect is on the uncensored latent variable, not the observed outcome (Wooldridge, 2001, p. 528). However, it is possible to obtain the effects of each independent variable on the conditional mean of the dependent variable by calculating marginal effects.
} 
Yönetim ve Ekonomi Araștırmaları Dergisi / Journal of Management and Economics Research Cilt/Volume: 15 Sayı/Issue: Özel Sayı 1/Special Issue 1 Aralık/December 2017 ss./pp. 188-211 Ö. Bilici Doi: http://dx.doi.org/10.11611/yead.373458

and Tenreyro, 2006; Martin and Pham, 2008; Prehn and Brummer, 2011; Tran et al, 2012), and most of these analyse the performance of PPML compared to other estimation approaches using country- or industry-level data. To the best of our knowledge, this is the first study that applies PPML to firm-level data.

\section{ANALYSES}

In order to analyse how the effects of different determinants of services trade might differ for firm-level services trade, we use three estimation approaches to estimate the gravity equation. Since the existing literature on firm-level analyses mostly uses OLS, it is also used in the current study to enable comparisons to be drawn. OLS is applied only to positive trade values. However, when the trade between all firms and all countries is considered, zero trade values are appeared. Although the ITIS reports only positive trade flows, we enlarge the dataset with zero trade values and use alternative approaches. The existence of zero trade flows leads to bias in the OLS estimations. We therefore employ two estimation approaches to deal with biased estimates. Tobit is the first approach which is used in the analyses. It is able to deal with zero trade values but its consistency depends on normal distribution as well. The second estimation approach used is the PPML. Under the correct specification of the conditional mean, it provides unbiased and consistent estimates in the presence of zero trade values and heteroskedasticity.

All analyses have been reported for the UK firm-level services exports and imports in 2005. In order to deal with correlated residuals across countries, country clusters are used to obtain clustercorrected standard error in all firm-level analyses ${ }^{7}$. We compare firm-level results with the results obtained from the aggregated data. To this end, we aggregate the firm-level data up to country level to repeat all the analyses. In addition to these analyses, we apply OLS and PPML on panel structured data to control for firm-by-service type fixed effects.

\subsection{Export Analysis}

Table 2 shows the results from the gravity equation estimated by OLS, PPML and Tobit for the UK firm-level exports. According to the table, all the variables except regional trade agreement have the expected signs. The coefficients for GDP, GDP per capita and distance are significant with expected signs, and the R\&D engagement variable is insignificant in all the models except PPML $(T \geq 0)$. The odd-numbered columns present the results for the models without firm-level variables, while the even-

\footnotetext{
${ }^{7}$ All firm-level analyses have been repeated with service type cluster-corrected standard errors since it is expected that firms operating within a specific service type might have similar properties. However, the significance levels of the coefficients remain the same in all the analyses.
} 
Yönetim ve Ekonomi Araștırmaları Dergisi / Journal of Management and Economics Research Cilt/Volume: 15 Sayı/Issue: Özel Sayı 1/Special Issue 1 Aralık/December 2017 ss./pp. 188-211 Ö. Bilici Doi: http://dx.doi.org/10.11611/yead.373458

numbered columns display the results with firm-level variables. The first and second columns of the table present the OLS results without and with firm-level variables respectively. The coefficients of the country-level variables are closer to each other in both estimations. GDP and GDP per capita of the trading partner country and the colonial relationship between the UK and the importing country have positive effects on the UK firm-level exports, whereas distance between the UK and the importing country, regional trade agreement, GATT membership and EU membership negatively affect the UK firm-level exports. The negative coefficients for the GATT membership and EU membership would be expected since these variables are the binary variables which are unity if the trading partner is a GATT/EU member and zero otherwise. Thus, they capture the degree of trade-diverting effects between members and non-members. However, the negative coefficient for the regional trade agreement variable is unexpected because it measures the degree of trade-creation effects of the regional trade agreement between the UK and her trading partners. After controlling for the size, productivity, age, legal status and $R \& D$ engagement of the firms, the magnitudes of country-level variables increase slightly. All firm-level variables have a significant effect on the firm-level exports. Accordingly, firm size and labour productivity and being an LLC have a significant positive effect on exports, while firm age has a negative effect.

Columns 3-4 and 5-6 depict the results of PPML. Since the ITIS reports trade statistics for only trading firms (no zero trade), PPML has been applied to the data provided by the ITIS ( $T>0$ ) and to the enlarged data, including zero export flows $(T \geq 0)$. The level of exports is used as the dependent variable in the PPML analyses. Both the coefficients and significance levels of the variables alter considerably in both regressions without and with firm characteristics. The results for PPML on positive export flows $(\mathrm{T}>0)$ are different from the results obtained from using OLS. This difference can be largely accounted for by the heteroskedacticity problem in the error term since these regressions are estimated only for positive export flows. Distance, colonial relationship and EU membership become insignificant while dummies for common legislation and common language turn out to be significant in the PPML $(T>0)$ regression without firm-level variables, and the coefficients from this regression are closer to the coefficients from the PPML $(T>0)$ regression with firm-level variables. However, distance has a significantly negative impact on export flows in the PPML $(T>0)$ regression with firmlevel variables.

When we consider zero trade flows by firms with a country in a specific service type, the coefficients obtained from PPML ( $T \geq 0$ ) are mostly higher than the coefficients obtained from OLS. GDP and GDP per capita of trading partner countries and distance have stronger effects on firm-level exports, according to the PPML results, showing that OLS underestimates these coefficients. PPML determines a significant positive effect for common legislation and common language. Moreover, 
Yönetim ve Ekonomi Araștırmaları Dergisi / Journal of Management and Economics Research Cilt/Volume: 15 Sayı/Issue: Özel Sayı 1/Special Issue 1 Aralık/December 2017 ss./pp. 188-211 Ö. Bilici Doi: http://dx.doi.org/10.11611/yead.373458

colonial relationship, regional trade agreements and EU membership turn out to be insignificant in the PPML ( $T \geq 0$ ) regression. The PPML results with the additional firm-level characteristics are closer to the PPML results without firm-level variables. With the firm-level variables, the effects of the coefficients obtained from PPML are still stronger than the results obtained from OLS. However, according to the PPML results, the effect of common legislation is significantly positive while the colonial relationship and dummies for regional trade agreements and EU membership have no significant effect on firm-level exports. Moreover, the dummy for being an LLC loses its significance in the PPML regression. Although most of the studies on goods trade (Duenas-Caparas, 2008; Roberts and Tybout, 1997; Niringiye and Tuyiragize, 2010; Majocchi et al, 2005) predict that firm age will have a positive effect, a negative relationship is also possible since the younger firms would be more flexible and quicker to adapt to changing international conditions and new technology. In the models with and without firm-level variables, the significant coefficients for regional trade agreement, GATT and EU memberships are all negative.

The Tobit model is an alternative to the PPML model designed to be able to deal with excess zeros. However, its validity depends on the normality assumption of error term. Columns 7 and 8 in Table 2 report the results of marginal effects (marginal effects on $E(y \mid X)$ from Tobit regressions with and without firm-level variables. The coefficient estimates from both regressions are smaller than both the estimations obtained from OLS and PPML. All the coefficients except the common language dummy, time difference variable and the EU membership dummy in the Tobit model without firm-level variables are significant and have expected signs. The Tobit model with the firm-level variables, firm age and $R \& D$ engagement have no significant effect on service exports. The coefficient for GATT becomes insignificant after adding firm-level variables. Moreover, adding these variables decreases the magnitude of the coefficients of country-level variables in the Tobit model while the opposite is true in the OLS estimations.

The last rows in Tables 2 gives the RESET test probability values for each model. Accordingly, the PPML $(T \geq 0)$ regression without firm variables strongly passes the test. However, the PPML ( $T \geq$ 0 ) regression with firm variables only passes the test weakly. This result may imply that the gravity equations estimated by the PPML provide truly specified estimations, showing that both the OLS and Tobit results report underestimated coefficients.

In order to take into consideration the firm-by-service type fixed effect, the OLS and the PPML methods are also applied to panel structured data. To this end, we generate a panel identification (id) category by grouping each firm by each service type. These panel ids and countries are then used to create a panel dataset. Since there are some firms that do not export to any of the countries included in the panel, some groups have been omitted. Moreover, since the firm-level variables are constant within 
Yönetim ve Ekonomi Araștırmaları Dergisi / Journal of Management and Economics Research Cilt/Volume: 15 Sayı/Issue: Özel Sayı 1/Special Issue 1 Aralık/December 2017 ss./pp. 188-211 Ö. Bilici Doi: http://dx.doi.org/10.11611/yead.373458

a group, the coefficients for these variables are not estimated. However, the results obtained with the firm-level variables are still comparable to the regressions without firm-level variables. The results are shown in Table 3.

According to Table 3, the fixed effect estimations confirm the aforementioned results. In particular, the PPML with fixed effects provides exactly the same results. Because the set of explanatory variables are the same and the PPML regression does not require the log transformation, it is invariant to the level of aggregation. In the OLS regressions, all the variables except common legislation have similar coefficients and significance levels. When we control for firm-by-service type fixed effects, the coefficient for common legislation becomes significant, showing that firm-level exports will be higher if the UK shares common legislation with the importing country. Moreover, the coefficients of regional trade agreement, GATT and EU memberships have a stronger effect on firm-level exports when we control for the firm-by-service type fixed effect. Adding firm-level variables does not change the magnitude and significance of country-level variables. The coefficients obtained from FE are lower than the coefficients obtained from the PPML fixed effect regressions. The RESET test results confirm that OLS underestimates the effect of variables on firm-level exports.

\subsection{Import Analysis}

In this section, the analyses described above are applied to the UK firm-level imports. Table 4 shows the results from the gravity equation estimated by OLS, PPML and Tobit for the UK firm-level imports. According to the OLS results in column 1 and 2 of the table, among the country-level variables, only GDP and distance are statistically significant. The magnitudes of the coefficients of significant variables are smaller than those obtained from the export analyses. There is little change in the coefficients after controlling for the firm characteristics. The effect of regional trade agreements turns out to be significant at the $10 \%$ significance level with the additional firm variables. However, its impact is negative, similarly to the export analyses. Firm age does not have a significant impact on firm-level imports, while firm size, labour productivity, R\&D engagement and the dummy for being an LLC have significant impacts on firm imports. Among the significant firm-level variables, $R \& D$ engagement has a negative impact on firm-level imports.

Columns 3-4 and 5-6 depict the PPML results. Since the ITIS reports trade statistics only for trading firms (no zero trade), as in the export analyses, PPML is applied to the data provided by the IT IS $(T>0)$ and to the enlarged data including zero import flows $(T \geq 0)$. The level of imports is used as the dependent variable in the PPML analyses. For the significant variables obtained through OLS with and without firm variables, the estimates obtained from PPML with positive export flows $(T>0)$ are closer to the results obtained from OLS, but in the PPML models, GDP per capita becomes significant. The regional trade agreement dummy turns out to be insignificant in the PPML analysis 
Yönetim ve Ekonomi Araștırmaları Dergisi / Journal of Management and Economics Research Cilt/Volume: 15 Sayı/Issue: Özel Sayı 1/Special Issue 1 Aralık/December 2017 ss./pp. 188-211 Ö. Bilici Doi: http://dx.doi.org/10.11611/yead.373458

$(T>0)$ with firm variables as well. For the significant firm characteristics, the magnitudes of the coefficients double in the PPML ( $\mathrm{T}>0$ ) regression. When we consider zero trade flows by firms with a country in a specific service type, the coefficients and significance levels of the variables obtained from PPML ( $T \geq 0$ ) alter considerably in the regressions without and with firm characteristics. They are higher than the coefficients obtained from OLS. GDP and GDP per capita of trading partner countries and distance have stronger effects on firm-level imports according to the PPML results, showing that OLS underestimates these coefficients. PPML determines a significant positive effect for colonial relationship and time difference variables. Although the PPML results with the additional firmlevel characteristics are closer to the PPML results without firm-level variables, after adding the firmlevel variables, time difference becomes insignificant. With the firm-level variables, the effects of the coefficients obtained from PPML are still stronger than the results obtained from OLS. Among the additional firm-level variables, only firm age is insignificant and the coefficients obtained from PPML are considerably higher than the coefficients obtained from OLS.

Columns 7 and 8 in Table 4 report the results of marginal effects (marginal effects on $E(y \mid X)$ ) from the Tobit regressions with and without firm-level variables. The coefficient estimates obtained from both regressions are smaller than both the OLS and PPML estimations. Only the dummies for common language, regional trade agreement and EU membership are insignificant in the Tobit model without firm-level variables and all significant coefficients have expected signs except time difference. The time difference variable has a positive impact contrary to expectations, showing that there is no need for time coordination between countries, while the language dummy is statistically insignificant. This result is valid for the Tobit model with firm-level variables as well. In this model, all the additional firm-level variables except firm age are significant. Moreover, adding these variables decreases the magnitude of the coefficients of country-level variables in the Tobit model while the opposite is true in the OLS and PPML models.

The last rows in Table 4 presents the RESET test probability values for each model. Accordingly, all the PPML regressions pass the test. This implies that the gravity equations estimated by the PPML provide truly specified estimations, showing that both the OLS and Tobit results report underestimated coefficients.

Following the export analyses, the OLS and the PPML are also applied to a panel structured data for UK imports in order to take into consideration the firm-by-service type fixed effect. To this end, we generate a panel id by grouping each firm by each service type. These panel ids and countries are used to create a panel data set. Since there are some firms that do not import from any of the countries, some groups have been omitted. Moreover, since the firm-level variables are constant within a group, the coefficients for these variables are not estimated. However, the results obtained with the 
Yönetim ve Ekonomi Arastırmaları Dergisi / Journal of Management and Economics Research Cilt/Volume: 15 Sayı/Issue: Özel Sayı 1/Special Issue 1 Aralı/December 2017 ss./pp. 188-211 Ö. Bilici Doi: http://dx.doi.org/10.11611/yead.373458

firm-level variables are still comparable to the regressions without the firm-level variables. The results are shown in Table 5. The last two columns in Table 5 present the PPML fixed effect results. The results are exactly the same as those shown in columns 5 and 6 in Table 4 . Since the regressors are the same, the coefficients do not change by changing the level of aggregation. However, the FE results differ from the OLS results shown in Table 4. The coefficients for colonial relationship and GATT membership become significant in the FE regressions while EU membership becomes insignificant. According to the FE estimations, firm-level imports in the UK are significantly affected by colonial relationship. Adding firm-level variables does not change the coefficients. However, when we control for firm characteristics, the effect of common legislation becomes insignificant, suggesting that additional firm characteristics are more important in determining service imports. As was the case with the export analyses, the coefficients obtained from the PPML fixed effect regressions are larger than the coefficients obtained from the FE regressions. However, in the import analyses, FE also passes the RESET test.

\subsection{Aggregate Analysis}

For the sake of completeness, we compared the results of this study with the analyses of the aggregated data obtained from the existing data, as well as earlier studies on country-level services exports and imports. Table 6 presents the OLS and PPML results obtained from the country-level data. In these analyses, firm-level exports and imports data are aggregated up to country level. The first four columns in Table 6 show the determinants of aggregate exports of the UK to 171 trading partners while the last four columns present the results obtained from the aggregate imports traded between the UK and 165 trading partners. According to the table, the coefficient of GDP is closer to 1 in the OLS regressions for both exports and imports but the effect is stronger for imports. Unlike for the disaggregated analyses, the OLS results are higher than the PPML results. GDP per capita is significant in the OLS regressions for exports while it is insignificant for imports. This implies that the development level of the partner country is a more important determinant for UK exports than for imports. The distance variable has an insignificant coefficient in the OLS regression for total exports while it is significant in the PPML regressions. It has a significant coefficient in all the import regressions, and the coefficients are closer to each other. Distance yields higher coefficients for aggregate imports in comparison to firm-level imports analyses. Among other country-level variables, colonial relationship is more important for imports while common language is of importance for services exports. GATT membership is a significant determinant only for exports; meanwhile, regional trade agreement is insignificant in all the analyses. The comparison of the results from firm-level analyses with the ones obtained from country-level analyses demonstrates that the OLS results are very sensitive to the aggregation level while the PPML is invariant to the level of aggregation when the 
Yönetim ve Ekonomi Araștırmaları Dergisi / Journal of Management and Economics Research Cilt/Volume: 15 Sayı/Issue: Özel Sayı 1/Special Issue 1 Aralık/December 2017 ss./pp. 188-211 Ö. Bilici Doi: http://dx.doi.org/10.11611/yead.373458

regressors are the same. This is another good property that PPML holds. Since for the PPML estimations, it is not necessary to take the log of dependent variable, the coefficients do not change by changing the level of aggregation. This implies that the PPML should be preferred not only because it provides consistent estimates in the presence of zero trade values and heteroskedasticity, but also because it provides similar coefficients in both firm-level and country-level analyses. PPML is also better at dealing with the problems arisen in aggregated data. There is no additional benefit of collapsing data down to firm-level.

These findings relating to aggregated exports and imports and their comparison to the disaggregated analyses (firm-level exports and imports) are mostly confirmed by the existing literature. The coefficients obtained from the firm-level exports and imports analyses are less than the coefficients found by the existing country-level studies (Kandilov and Grennes, 2010, 2012; Walsh, 2006; Kimura and Lee, 2006). According to these studies, GDP, GDP per capita, common language, colonial relationship and regional trade agreements have a positive impact on services trade while distance has a negative impact. The coefficients for GDP and GDP per capita are closer to 1 while distance has a coefficient which is generally higher than 0.6 . The magnitudes of the coefficients for these variables are smaller for the firm-level analyses. This shows that when the country-level trade data is disaggregated by firms, the coefficients change considerably, suggesting that the policies followed according to the results obtained from the country-level analyses do not fit all of the trading firms. Since each firm has different characteristics, they also have different motivations for trade. As stated by Chaney $(2005,2008)$, differences between firms in terms of size or productivity reduce the effects of trade barriers on trade flows. Kimura and Lee (2006), compare the coefficients of country-level exports and imports. They find that the coefficients of the variables mentioned above are slightly stronger for service exports than imports. Although the coefficients decrease significantly with disaggregation, the pattern remains the same; the policies implemented to affect trade flows would affect service exports more than service imports in the case of both firm-level and country-level trade.

\section{CONCLUSION}

In this study, we examine the determinants of services trade for UK firms. To this end, we combine the unique firm-level services trade data - ITIS - provided by the UK Office for National Statistics with different firm-level and country-level data sources. Three estimation approaches are used to estimate the gravity equation in order to analyse how the effects of different determinants of services trade may vary across firms with different characteristics. Since the existing literature on firm-level analyses mostly uses OLS, it is also used in this study to enable comparisons. The dataset is then 
Yönetim ve Ekonomi Arastırmaları Dergisi / Journal of Management and Economics Research Cilt/Volume: 15 Sayı/Issue: Özel Sayı 1/Special Issue 1 Aralı/December 2017 ss./pp. 188-211 Ö. Bilici Doi: http://dx.doi.org/10.11611/yead.373458

enlarged with zero trade flows since the ITIS reports only positive trade values for each firm with a particular country in a particular service type. This enables us to apply the PPML and Tobit models to deal with the presence of zero trade flows and to obtain more accurate results. Among these models, the PPML is the only model which also considers the heteroskedastic error term in the multiplicative form of the gravity equation. It provides consistent estimates under the correct specification of the mean of the dependent variable. Therefore, PPML is the preferred model since it is able to deal with both of the aforementioned problems and the RESET test results confirm this prediction.

The results show that the gravity equation is successful in explaining the determinants of firmlevel service exports and imports. Distance has a negative impact on firm-level service exports and imports, and the coefficients are lower in comparison to the country-level analysis results. In the firmlevel data, the coefficients of other determinants change considerably compared to the aggregate analysis. This might suggest that the policies based on results from country-level analyses might not fit all the trading firms. The comparison of the firm-level results with the country-level results shows that the OLS results are very sensitive to the aggregation level while the PPML is invariant to the level of aggregation when the regressors are the same. There is no additional benefit of collapsing data down to firm-level. This can be considered as another good property that PPML holds. For the PPML estimations, it is not necessary to take the log of dependent variable, the coefficients do not change by changing the level of aggregation. This implies that the PPML should be preferred not only because it provides consistent estimates in the presence of zero trade values and heteroskedasticity, but also because it provides similar coefficients in both firm-level and country-level analyses.

\section{REFERENCES}

Amiti, M. and Wei S. (2005) "Fear of service outsourcing: is it justified?", Economic Policy, 20(42):308-347

Angrist, J. and Pischke, J.S. (2009) Mostly Harmless Econometrics: An Empiricist's Companion, Princeton University Press

Ariu, A (2010) "The margins of trade in services", http://www.bgse.uni-bonn.de/graduate-program1/exchange-program/edp-papers/ariu, accessed: 2012-09-06

Bhagwati, J.N. (1984) "Splintering and disembodiment of services and developing nations", World Economy, 7(2):133-144 
Yönetim ve Ekonomi Araștırmaları Dergisi / Journal of Management and Economics Research Cilt/Volume: 15 Sayı/Issue: Özel Sayı 1/Special Issue 1 Aralık/December 2017 ss./pp. 188-211 Ö. Bilici Doi: http://dx.doi.org/10.11611/yead.373458

Breinlich, H. and Criscuolo, C. (2011) "International trade in services: A portrait of importers and exporters", Journal of International Economics, 84(2):188-206

Chaney, T. (2005) "Distorted gravity: Heterogeneous firms, market structure, and the geography of international trade" http://sticerd.lse.ac.uk/seminarpapers/special21022005.pdf, accessed: 2012-09-06

Chaney, T .(2008) "Distorted Gravity: The Intensive and Extensive Margins of International Trade", American Economic Review, 98(4):1707-21

Christen, E. and Francois, J. (2010) "Modes of Delivery in Services”, Discussion Papers 7912, CEPR

Deardorff, A.V. (2001) "International Provision of Trade Services, Trade, and Fragmentation", Review of International Economics, 9(2):233-48

Duenas-Caparas M.T.S. (2008) "Firm-Level Determinants of Export Performance: Evidence from the Philippines", Philippine Journal of Development PJD 2007 Vol. XXXIV No. 1, Philippine Institute for Development Studies

Eaton, J. and Tamura, A. (1994) "Bilateralism and Regionalism in Japanese and U.S. Trade and Direct Foreign Investment Patterns", Journal of the Japanese and International Economies, 8(4):478510

Federico, S. and Tosti, E. (2012) "Exporters and importers of services: firm-level evidence on Italy", Temi di discussione (Economic working papers) 877, Bank of Italy, Economic Research and International Relations Area

Francois, J. and Hoekman, B. (2010) "Services trade and policy", Journal of Economic Literature, 48(3):642-92, DOI 10.1257/jel.48.3.642

Francois, J. and Wooton, I. (2001) "Market structure, trade liberalization and the GATS", European Journal of Political Economy, 17(2):389-402

Francois, J.F. (1993) "Explaining the Pattern of Trade in Producer Services", International Economic Journal, 7(3):23-31, DOI 10.1080/10168739300000002

Freund, C. and Weinhold, D. (2002) "The Internet and International Trade in Services", American Economic Review, 92(2):236-240

Grunfeld, L.A. and Moxnes, A. (2003) "The Intangible Globalization: Explaining the Patterns of International Trade in Services", Discussion papers, Norwegian Institute of International Affairs 
Yönetim ve Ekonomi Araștırmaları Dergisi / Journal of Management and Economics Research Cilt/Volume: 15 Sayı/Issue: Özel Sayı 1/Special Issue 1 Aralık/December 2017 ss./pp. 188-211 Ö. Bilici Doi: http://dx.doi.org/10.11611/yead.373458

Head, K. and Mayer, T. (2013) “Gravity Equations: Workhorse, Toolkit, and Cookbook”, Working Papers 2013-7, CEPII Research Center

Head, K., Mayer, T. and Ries, J. (2009) "How remote is the offshoring threat?", European Economic Review, 53(4):429-444

Head, K., Mayer, T. and Ries, J (2010) “The erosion of colonial trade linkages after independence”, Journal of International Economics, 81(1):1-14

Kandilov, I.T. and Grennes, T. (2010) "The determinants of service exports from Central and Eastern Europe", The Economics of Transition, 18(4):763-794

Kandilov, I.T. and Grennes, T. (2012) “The determinants of service offshoring: Does distance matter?”, Japan and the World Economy, 24(1):36-43

Kelle, M. and Kleinert, J. (2010) “German Firms in Service Trade", Applied Economics Quarterly (formerly: Konjunkturpolitik), 56(1):51-72

Kimura, F. and Lee, H.H. (2006) "The Gravity Equation in International Trade in Services", Review of World Economics (Weltwirtschaftliches Archiv), 142(1):92-121

Lennon, C. (2009) “Trade in Services and Trade in Goods: Differences and Complementarities”, WIIW Working Papers 53, The Vienna Institute for International Economic Studies

Majocchi, A., Bacchiocchi, E. and Mayrhofer, U. (2005) "Firm size, business experience and export intensity in SMEs: A longitudinal approach to complex relationships", International Business Review, 14(6):719-738

Martin, W. and Pham, C.S. (2008) "Estimating the Gravity Model when Zero Trade Flows are Frequent", Economics Series 2008_03, Deakin University, Faculty of Business and Law, School of Accounting, Economics and Finance

McCann, F. and Toubal, F. (2011) “The geographic scope of trade: Firm-level evidence on similarities between goods and services", http://www.etsg.org/ETSG2011/Papers/McCann.pdf, accessed: 2012-09-06

Mirza, D. and Nicoletti, G. (2004) "What is so special about trade in services", Research Papers 2004/02, University of Nottingham

Moulton, B.R. (1990) “An Illustration of a Pitfall in Estimating the Effects of Aggregate Variables on Micro Unit", The Review of Economics and Statistics, 72(2):334-38 
Yönetim ve Ekonomi Araștırmaları Dergisi / Journal of Management and Economics Research Cilt/Volume: 15 Sayı/Issue: Özel Sayı 1/Special Issue 1 Aralık/December 2017 ss./pp. 188-211 Ö. Bilici Doi: http://dx.doi.org/10.11611/yead.373458

Niringiye, A. and Tuyiragize, R. (2010) “Determinants of a Firm's Level of Exports: Evidence from Manufacturing Firms in Uganda", Research Papers 196, African Economic Research Consortium

ONS (2011) International Trade in Services Surveys, 1996-2005: Secure Data Service Access [computer file]. http://dx.doi.org/10.5255/UKDA-SN-6697-5

ONS (2012) Annual Respondents Database, 1973-2008: Secure Data Service Access [computer file]. http://dx.doi.org/10.5255/UKDA-SN-6644-5

ONS (2015) Business Structure Database, 1997-2014: Secure Access [computer file]. http://dx.doi.org/10.5255/UKDA-SN-6697-5

Poyhonen, P. (1963) "A tentative model for the volume of trade between countries", Weltwirtschaftliches Archiv, 90:93-100

Prehn, S. and Brummer, B. (2011) "Estimation Issues In Single Commodity Gravity Trade Models", 51st Annual Conference, Halle, Germany, September 28-30, 2011 114524, German Association of Agricultural Economists (GEWISOLA)

Roberts, M.J. and Tybout, J.R. (1997) "The Decision to Export in Colombia: An Empirical Model of Entry with Sunk Costs", American Economic Review, 87(4):545-64

Silva, J.M.C.S. and Tenreyro, S. (2006) “The Log of Gravity”, The Review of Economics and Statistics, 88(4):641-658

Tharakan, P.K.M., Beveren, I.V. and Ourti, T.V. (2005) “Determinants of India's Software Exports and Goods Exports", The Review of Economics and Statistics, 87(4):776-780

Timbergen, J. (1962) Shaping the World Economy; Suggestions for an International Economic Policy, Twentieth Century Fund, New York

Tran, N., Wilson, N. and Hite, D. (2012) "Choosing the best model in the presence of zero trade: a fish product analysis", No. 40064 in Working Papers, The World Fish Centre.

Walsh, K. (2006) "Trade in Services: Does Gravity Hold? A Gravity Model Approach to Estimating Barriers to Services Trade", The Institute for International Integration Studies Discussion Paper Series 183, IIIS

Wooldridge, J.M. (2001) Econometric Analysis of Cross Section and Panel Data, MIT Press Books, vol 1. The MIT Press 
Yönetim ve Ekonomi Araștırmaları Dergisi / Journal of Management and Economics Research Cilt/Volume: 15 Sayı/Issue: Özel Sayı 1/Special Issue 1 Aralık/December 2017 ss./pp. 188-211 Ö. Bilici Doi: http://dx.doi.org/10.11611/yead.373458

WTO (2011) World Trade Organization International Trade Statistics 2011. http://www.wto.org/english/res_e/statis_e/its2011_e/its11_toc_e.htm, accessed: 2011-03-01

\section{TABLES}

Table 1: Explanation of the Variables used in the Estimations

\begin{tabular}{|c|c|c|c|c|}
\hline & Explanations & Variable & Sources & $\begin{array}{l}\text { Expected } \\
\text { Sign }\end{array}$ \\
\hline \multirow{3}{*}{$\begin{array}{l}\text { Dependent } \\
\text { Variables }\end{array}$} & UK firm-level exports to the trading partners & Export & ITIS & \\
\hline & $\begin{array}{l}\text { UK firm-level imports from the trading } \\
\text { partners }\end{array}$ & Import & ITIS & \\
\hline & $\begin{array}{l}\text { UK firm total exports/imports to/from the } \\
\text { trading partners }\end{array}$ & $\begin{array}{l}\text { Total } \\
\text { export/import }\end{array}$ & & \\
\hline \multirow{12}{*}{$\begin{array}{l}\text { Explanatory } \\
\text { Variables }\end{array}$} & GDP of trading partner (current mn US\$) & GDP partner & CEPII & + \\
\hline & $\begin{array}{l}\text { GDP per capita of trading partner (current mn } \\
\text { US\$) }\end{array}$ & GDPPC partner & CEPII & + \\
\hline & $\begin{array}{l}\text { Population-weighted great circle distance } \\
\text { between large cities of the UK and her trading } \\
\text { partners }\end{array}$ & Distance & CEPII & - \\
\hline & $\begin{array}{l}\text { Number of hours difference between the UK } \\
\text { and her trading partner }\end{array}$ & Time difference & CEPII & $+/-$ \\
\hline & $\begin{array}{l}\text { Dummy variable for colonial relationship; } 1 \text { if } \\
\text { the UK and her trading partner ever in colonial } \\
\text { relationship }\end{array}$ & $\begin{array}{l}\text { Colonial } \\
\text { relationship }\end{array}$ & CEPII & + \\
\hline & $\begin{array}{l}\text { Dummy variable for common legislation; } 1 \text { if } \\
\text { the UK and her trading partner have common } \\
\text { legal origin }\end{array}$ & $\begin{array}{l}\text { Common } \\
\text { legislation }\end{array}$ & CEPII & + \\
\hline & $\begin{array}{l}\text { Dummy variable for Common language; } 1 \text { if a } \\
\text { language is spoken by at least } 9 \% \text { of the } \\
\text { population in the UK and her trading partner }\end{array}$ & $\begin{array}{l}\text { Common } \\
\text { language }\end{array}$ & CEPII & + \\
\hline & $\begin{array}{l}\text { Dummy variable for regional trade agreement; } \\
1 \text { for regional trade agreement in force between } \\
\text { the UK and her trading partner }\end{array}$ & $\begin{array}{l}\text { Regional trade } \\
\text { agreement }\end{array}$ & CEPII & + \\
\hline & $\begin{array}{l}\text { Dummy variable for GATT/WTO } \\
\text { membership; } 1 \text { if the UK and her trading } \\
\text { partner are members of GATT/WTO }\end{array}$ & $\begin{array}{l}\text { GATT } \\
\text { membership }\end{array}$ & CEPII & + \\
\hline & $\begin{array}{l}\text { Dummy variable for EU membership; } 1 \text { if the } \\
\text { UK and her trading partner are members of } \\
\text { EU }\end{array}$ & & & \\
\hline & Total number of employees, point in time & \# of employees & ARD & + \\
\hline & Gross value added per employee & $\begin{array}{l}\text { Labour } \\
\text { productivity }\end{array}$ & ARD & + \\
\hline
\end{tabular}


Yönetim ve Ekonomi Araștırmaları Dergisi / Journal of Management and Economics Research Cilt/Volume: 15 Sayı/Issue: Özel Sayı 1/Special Issue 1 Aralık/December 2017 ss./pp. 188-211 Ö. Bilici Doi: http://dx.doi.org/10.11611/yead.373458

Research and development engagement dummy: 1 if the firm is engaged in $R \& D$ activities

Age of the firm

Dummy for legal status of the firm; 1 is the firm is an LLC
R\&D

engagement

ARD

Age of the firm

BSD

LLC

BSD

Table 2: Firm-level Exports: OLS, PPML and Tobit

\begin{tabular}{|c|c|c|c|c|c|c|c|c|}
\hline & $\begin{array}{l}\text { (1) } \\
\text { OLS }\end{array}$ & $\begin{array}{l}\text { (2) } \\
\text { OLS }\end{array}$ & $\begin{array}{c}(3) \\
\text { PPML } \\
(T>0)\end{array}$ & $\begin{array}{c}(4) \\
\text { PPML } \\
(T>0)\end{array}$ & $\begin{array}{c}(5) \\
\text { PPML }\end{array}$ & $\begin{array}{c}(6) \\
\text { PPML }\end{array}$ & $\begin{array}{c}(7) \\
\text { TOBIT }\end{array}$ & $\begin{array}{c}(8) \\
\text { TOBIT }\end{array}$ \\
\hline Dependent Variable & $\begin{array}{l}\text { Log of } \\
\text { Exports }\end{array}$ & $\begin{array}{l}\text { Log of } \\
\text { Exports }\end{array}$ & Exports & Exports & Exports & Exports & Exports & Exports \\
\hline Log of GDP partner & $\begin{array}{r}0.262 * * * \\
(9.42)\end{array}$ & $\begin{array}{r}0.281 * * * \\
(10.40)\end{array}$ & $\begin{array}{r}0.229 * * * \\
(4.94)\end{array}$ & $\begin{array}{r}0.289 * * * \\
(6.47)\end{array}$ & $\begin{array}{r}0.616^{* * *} \\
(15.14)\end{array}$ & $\begin{array}{r}0.628 * * * \\
(15.37)\end{array}$ & $\begin{array}{r}0.252 * * * \\
(4.75)\end{array}$ & $\begin{array}{r}0.167 * * * \\
(6.58)\end{array}$ \\
\hline Log of GDPPC partner & $\begin{array}{r}0.0978 * * * \\
(2.68)\end{array}$ & $\begin{array}{r}0.108 * * * * \\
(2.81)\end{array}$ & $\begin{array}{r}0.354^{* * * *} \\
(2.92)\end{array}$ & $\begin{array}{r}0.415 * * * \\
(4.33)\end{array}$ & $\begin{array}{r}0.516 * * * \\
(3.59)\end{array}$ & $\begin{array}{r}0.549 * * * \\
(4.36)\end{array}$ & $\begin{array}{r}0.102 * * * \\
(4.00)\end{array}$ & $\begin{array}{r}0.068^{* * * *} \\
(4.48)\end{array}$ \\
\hline Log of distance & $\begin{array}{r}-0.375 * * * \\
(-5.61)\end{array}$ & $\begin{array}{r}-0.413 * * * \\
(-5.85)\end{array}$ & $\begin{array}{l}-0.192 \\
(-0.99)\end{array}$ & $\begin{array}{r}-0.275^{*} \\
(-1.81)\end{array}$ & $\begin{array}{r}-0.569 * * * \\
(-2.74)\end{array}$ & $\begin{array}{r}-0.625 * * * \\
(-3.39)\end{array}$ & $\begin{array}{r}-0.187 * * \\
(-2.96)\end{array}$ & $\begin{array}{r}-0.126 * * * \\
(-3.41)\end{array}$ \\
\hline Colonial relationship & $\begin{array}{r}0.294 * * * \\
(2.59)\end{array}$ & $\begin{array}{r}0.366 * * * \\
(3.39)\end{array}$ & $\begin{array}{l}-0.931 \\
(-1.61)\end{array}$ & $\begin{array}{l}-0.721 \\
(-1.52)\end{array}$ & $\begin{array}{l}-0.347 \\
(-1.15)\end{array}$ & $\begin{array}{l}-0.319 \\
(-0.98)\end{array}$ & $\begin{array}{r}0.230^{* *} \\
(2.42)\end{array}$ & $\begin{array}{r}0.158^{* * * *} \\
(2.67)\end{array}$ \\
\hline Common legislation & $\begin{array}{r}0.0237 \\
(0.25)\end{array}$ & $\begin{array}{r}0.0638 \\
(0.67)\end{array}$ & $\begin{array}{r}0.308^{* *} \\
(1.46)\end{array}$ & $\begin{array}{r}0.371^{*} \\
(1.70)\end{array}$ & $\begin{array}{r}0.732 * * * \\
(3.48)\end{array}$ & $\begin{array}{r}0.673 * * * \\
(2.93)\end{array}$ & $\begin{array}{r}0.236^{* *} \\
(2.43)\end{array}$ & $\begin{array}{r}0.152 * * \\
(2.52)\end{array}$ \\
\hline Common language & $\begin{array}{r}0.0428 \\
(0.50)\end{array}$ & $\begin{array}{r}0.0178 \\
(0.22)\end{array}$ & $\begin{array}{r}1.228^{* *} \\
(2.07)\end{array}$ & $\begin{array}{r}1.005^{* * *} \\
(2.20)\end{array}$ & $\begin{array}{r}0.866 * * * \\
(3.00)\end{array}$ & $\begin{array}{r}0.858^{* * * *} \\
(2.79)\end{array}$ & $\begin{array}{l}0.052 \\
(1.03)\end{array}$ & $\begin{array}{r}0.034 \\
(1.04)\end{array}$ \\
\hline Time difference & $\begin{array}{r}-0.0214 \\
(-0.71)\end{array}$ & $\begin{array}{r}-0.0220 \\
(-0.74)\end{array}$ & $\begin{array}{r}-0.119 \\
(-1.46)\end{array}$ & $\begin{array}{r}-0.112 \\
(-1.48)\end{array}$ & $\begin{array}{r}-0.0265 \\
(-0.44)\end{array}$ & $\begin{array}{r}-0.0212 \\
(-0.34)\end{array}$ & $\begin{array}{l}0.012 \\
(0.96)\end{array}$ & $\begin{array}{r}0.008 \\
(0.96)\end{array}$ \\
\hline Regional trade agreement & $\begin{array}{r}-0.383 * * \\
(-1.89)\end{array}$ & $\begin{array}{r}-0.368^{* *} \\
(-2.18)\end{array}$ & $\begin{array}{l}-0.657 \\
(-1.59)\end{array}$ & $\begin{array}{r}-0.572 \\
(-1.45)\end{array}$ & $\begin{array}{r}0.0435 \\
(0.12)\end{array}$ & $\begin{array}{r}-0.00777 \\
(-0.02)\end{array}$ & $\begin{array}{r}0.221 * * \\
(1.97)\end{array}$ & $\begin{array}{r}0.141^{*} \\
(1.94)\end{array}$ \\
\hline GATT membership & $\begin{array}{r}-0.380^{*} \\
(-1.89)\end{array}$ & $\begin{array}{r}-0.402^{* *} \\
(-1.99)\end{array}$ & $\begin{array}{r}-1.154 * * * \\
(-3.23)\end{array}$ & $\begin{array}{r}-1.345^{* *} \\
(-3.85)\end{array}$ & $\begin{array}{r}-0.910^{* *} \\
(-2.41)\end{array}$ & $\begin{array}{r}-1.006^{* * *} \\
(-2.60)\end{array}$ & $\begin{array}{r}0.066^{* *} \\
(0.96)\end{array}$ & $\begin{array}{r}0.041 \\
(0.93)\end{array}$ \\
\hline $\begin{array}{l}\text { European Union } \\
\text { membership }\end{array}$ & $\begin{array}{r}-0.258^{*} \\
(-1.82)\end{array}$ & $\begin{array}{r}-0.311 * * \\
(-2.11)\end{array}$ & $\begin{array}{l}-0.222 \\
(-0.57)\end{array}$ & $\begin{array}{r}-0.490 * * \\
(-1.40)\end{array}$ & $\begin{array}{r}-0.0754 \\
(-0.14)\end{array}$ & $\begin{array}{l}-0.248 \\
(-0.51)\end{array}$ & $\begin{array}{l}0.121 \\
(1.30)\end{array}$ & $\begin{array}{l}0.077 \\
(1.24)\end{array}$ \\
\hline Log of \# of employees & & $\begin{array}{r}0.379 * * * \\
(24.84)\end{array}$ & & $\begin{array}{r}0.507 * * * \\
(15.65)\end{array}$ & & $\begin{array}{r}0.617 * * * \\
(15.48)\end{array}$ & & $\begin{array}{r}0.070 * * * \\
(6.32)\end{array}$ \\
\hline Log of labor productivity & & $\begin{array}{r}0.490 * * * \\
(32.77)\end{array}$ & & $\begin{array}{r}0.610 * * * \\
(27.23)\end{array}$ & & $\begin{array}{r}0.755^{* * * *} \\
(19.65)\end{array}$ & & $\begin{array}{r}0.112^{* * * *} \\
(6.35)\end{array}$ \\
\hline Log of age of the firm & & $\begin{array}{r}-0.327 * * * \\
(-10.76)\end{array}$ & & $\begin{array}{r}-0.321 * * * \\
(-5.72)\end{array}$ & & $\begin{array}{r}-0.360 * * * \\
(-7.67)\end{array}$ & & $\begin{array}{l}0.043 \\
(4.55)\end{array}$ \\
\hline Dummy for being an LLC & & $\begin{array}{r}0.741 * * * \\
(13.85)\end{array}$ & & $\begin{array}{r}0.872 * * * \\
(7.05)\end{array}$ & & $\begin{array}{r}0.119 \\
(1.01)\end{array}$ & & $\begin{array}{r}-0.290 * * * \\
(-5.05)\end{array}$ \\
\hline$R \& D$ engagement & & $\begin{array}{r}0.150 * * * \\
(4.07)\end{array}$ & & $\begin{array}{r}0.281 * * * \\
(3.30)\end{array}$ & & $\begin{array}{r}0.367 * * * \\
(3.10)\end{array}$ & & $\begin{array}{l}0.024 \\
(1.48)\end{array}$ \\
\hline Constant & $\begin{array}{r}4.717 * * * \\
(6.96) \\
\end{array}$ & $\begin{array}{r}0.982 \\
(1.37)\end{array}$ & $\begin{array}{r}4.506^{* * *} \\
(2.12) \\
\end{array}$ & $\begin{array}{l}-1.296 \\
(-0.72)\end{array}$ & $\begin{array}{l}-3.470 \\
(-1.55)\end{array}$ & $\begin{array}{r}-9.241 * * * \\
(-4.53) \\
\end{array}$ & & \\
\hline $\mathrm{N}$ & 16,252 & 15,726 & 16,252 & 15,726 & $15,148,899$ & $14,608,164$ & $15,148,899$ & $14,608,164$ \\
\hline $\begin{array}{l}\text { R-squared } \\
\text { RESET(p-values) }\end{array}$ & $\begin{array}{l}0.072 \\
0.000\end{array}$ & $\begin{array}{l}0.173 \\
0.000\end{array}$ & $\begin{array}{l}0.009 \\
0.000\end{array}$ & $\begin{array}{r}0.078 \\
0.0476\end{array}$ & $\begin{array}{r}0.002 \\
0.8146\end{array}$ & $\begin{array}{r}0.001 \\
0.0199\end{array}$ & $\begin{array}{r}0.060 \\
0.0169\end{array}$ & $\begin{array}{r}0.067 \\
0.0021\end{array}$ \\
\hline
\end{tabular}

The dependent variable is the value of service exports incurred by each firm. The log of exports is used in OLS estimations. t-statistics (from OLS) and z-statistics (from PPML and Tobit) in parentheses are calculated based on country clustered robust standard errors. Pseudo R-squared in Tobit regressions. p-values of RESET test for the model in each column is provided in the last row. Column 7 and 8 provide the marginal effects (marginal effects on $\mathrm{E}(\mathrm{yj} \mathrm{X})$ ) from Tobit regressions. * Significant at the $10 \%$ level, ** Significant at the 5\% level, *** Significant at the $1 \%$ level. 
Yönetim ve Ekonomi Araștırmaları Dergisi / Journal of Management and Economics Research Cilt/Volume: 15 Sayı/Issue: Özel Sayı 1/Special Issue 1 Aralık/December 2017 ss./pp. 188-211 Ö. Bilici Doi: http://dx.doi.org/10.11611/yead.373458

Table 3: Firm-level Exports Analyses with Firm-by-service Type Fixed Effects

\begin{tabular}{|c|c|c|c|c|c|c|}
\hline & $\begin{array}{c}\text { (1) } \\
\text { FE w/o firm } \\
\text { variables }\end{array}$ & $\begin{array}{c}\text { (2) } \\
\text { FE w/ firm } \\
\text { variables }\end{array}$ & $\begin{array}{c}(3) \\
\text { Poisson }(\mathrm{T}>0) \mathrm{w} / \mathrm{o} \\
\text { firm variables }\end{array}$ & $\begin{array}{c}(4) \\
\text { Poisson }(\mathrm{T}>0) \\
\text { w/ firm } \\
\text { variables } \\
\end{array}$ & $\begin{array}{c}\text { (5) } \\
\text { Poisson w/o } \\
\text { firm variables }\end{array}$ & $\begin{array}{l}(6) \\
\text { Poisson w/ } \\
\text { firm } \\
\text { variables } \\
\end{array}$ \\
\hline Dependent Variable & $\begin{array}{l}\text { Log of } \\
\text { Exports }\end{array}$ & $\begin{array}{l}\text { Log of } \\
\text { Exports }\end{array}$ & Exports & Exports & Exports & Exports \\
\hline Log of GDP partner & $\begin{array}{c}0.289 * * * \\
(22.03)\end{array}$ & $\begin{array}{c}0.286 * * * \\
(21.40)\end{array}$ & $\begin{array}{c}0.243 * * * \\
(4.20)\end{array}$ & $\begin{array}{c}0.287 * * * \\
(7.11)\end{array}$ & $\begin{array}{c}0.616 * * * \\
(16.39)\end{array}$ & $\begin{array}{c}0.628^{* * * *} \\
(16.83)\end{array}$ \\
\hline Log of GDPPC partner & $\begin{array}{c}0.105^{* * * *} \\
(5.85)\end{array}$ & $\begin{array}{c}0.110 * * * \\
(6.01)\end{array}$ & $\begin{array}{c}0.239 * * * \\
(3.63)\end{array}$ & $\begin{array}{c}0.246 * * * \\
(4.56)\end{array}$ & $\begin{array}{c}0.516 * * * \\
(4.06)\end{array}$ & $\begin{array}{c}0.549 * * * \\
(5.38)\end{array}$ \\
\hline Log of distance & $\begin{array}{c}-0.412 * * * \\
(-12.28)\end{array}$ & $\begin{array}{c}-0.409 * * * \\
(-12.10)\end{array}$ & $\begin{array}{l}-0.255 \\
(-1.34)\end{array}$ & $\begin{array}{c}-0.296 * * * \\
(-2.86)\end{array}$ & $\begin{array}{c}-0.569 * * * \\
(-2.97)\end{array}$ & $\begin{array}{c}-0.625 * * * \\
(-4.89)\end{array}$ \\
\hline Colonial relationship & $\begin{array}{c}0.414^{* * * *} \\
(5.41)\end{array}$ & $\begin{array}{c}0.417 * * * \\
(5.39)\end{array}$ & $\begin{array}{l}-0.226 \\
(-1.00)\end{array}$ & $\begin{array}{l}-0.148 \\
(-0.75)\end{array}$ & $\begin{array}{l}-0.347 \\
(-0.80)\end{array}$ & $\begin{array}{l}-0.319 \\
(-0.68)\end{array}$ \\
\hline Common legislation & $\begin{array}{c}0.162 * * * \\
(2.63)\end{array}$ & $\begin{array}{c}0.154 * * \\
(2.47)\end{array}$ & $\begin{array}{c}0.355^{*} \\
(1.91)\end{array}$ & $\begin{array}{l}0.248 \\
(1.37)\end{array}$ & $\begin{array}{c}0.732 * * * \\
(5.31)\end{array}$ & $\begin{array}{c}0.673^{* * * *} \\
(4.39)\end{array}$ \\
\hline Common language & $\begin{array}{r}0.0369 \\
(0.67)\end{array}$ & $\begin{array}{r}0.0342 \\
(0.62)\end{array}$ & $\begin{array}{c}0.478 * * \\
(2.20)\end{array}$ & $\begin{array}{c}0.443 * * \\
(2.17)\end{array}$ & $\begin{array}{l}0.866^{*} \\
(1.67)\end{array}$ & $\begin{array}{l}0.858 \\
(1.53)\end{array}$ \\
\hline Time difference & $\begin{array}{c}-0.0126 \\
(-1.11)\end{array}$ & $\begin{array}{c}-0.0125 \\
(-1.08)\end{array}$ & $\begin{array}{c}-0.0611 * * \\
(-1.96)\end{array}$ & $\begin{array}{c}-0.0781 * * * \\
(-2.94)\end{array}$ & $\begin{array}{c}-0.0265 \\
(-0.60)\end{array}$ & $\begin{array}{c}-0.0212 \\
(-0.49)\end{array}$ \\
\hline \multirow{2}{*}{$\begin{array}{l}\text { Regional trade } \\
\text { agreement }\end{array}$} & $-0.274 * * *$ & $-0.268 * * *$ & $-0.368 * *$ & $-0.505^{* * *}$ & 0.0435 & -0.00777 \\
\hline & $(-4.11)$ & $(-3.92)$ & $(-1.99)$ & $(-2.79)$ & $(0.22)$ & $(-0.04)$ \\
\hline GATT membership & $\begin{array}{c}-0.242 * * * \\
(-3.58)\end{array}$ & $\begin{array}{c}-0.261 * * * \\
(-3.80)\end{array}$ & $\begin{array}{c}-0.939 * * * \\
(-5.07)\end{array}$ & $\begin{array}{c}-0.892 * * * \\
(-4.86)\end{array}$ & $\begin{array}{c}-0.910 * * * \\
(-3.16)\end{array}$ & $\begin{array}{c}-1.006 * * * \\
(-3.51)\end{array}$ \\
\hline EU membership & $\begin{array}{c}-0.115^{* *} * \\
(-2.38)\end{array}$ & $\begin{array}{c}-0.123 * * \\
(-2.48)\end{array}$ & $\begin{array}{c}0.0383 \\
(0.12)\end{array}$ & $\begin{array}{l}-0.219 \\
(-1.19)\end{array}$ & $\begin{array}{c}-0.0754 \\
(-0.26)\end{array}$ & $\begin{array}{l}-0.248 \\
(-1.08)\end{array}$ \\
\hline $\begin{array}{l}\mathrm{N} \\
\text { RESET (p-values) }\end{array}$ & $\begin{array}{l}16252 \\
0.000\end{array}$ & $\begin{array}{l}15726 \\
0.000\end{array}$ & $\begin{array}{l}15360 \\
0.0768\end{array}$ & $\begin{array}{l}14868 \\
0.0052\end{array}$ & $\begin{array}{l}422145 \\
\mathbf{0 . 6 6 8 0}\end{array}$ & $\begin{array}{l}406923 \\
\mathbf{0 . 3 2 2 9}\end{array}$ \\
\hline
\end{tabular}

In order to produce these results, a panel dataset is created based on countries and panel ids that are generated by grouping each firm by each service type then firm-by-service type FE included in all models. The dependent variable is the value of service exports incurred by each firm. The log of exports is used in OLS estimations. tstatistics (from OLS) and z-statistics (from PPML) in parentheses are calculated based on heteroskedasticity robust standard errors. p-values of RESET test for the model in each column is provided in the last row. * Significant at the $10 \%$ level, $* *$ Significant at the $5 \%$ level, $* * *$ Significant at the $1 \%$ level

Table 4: Firm-level Imports: OLS, PPML and Tobit

\begin{tabular}{|c|c|c|c|c|c|c|c|c|}
\hline & $\begin{array}{c}(1) \\
\text { OLS }\end{array}$ & $\begin{array}{l}(2) \\
\text { OLS }\end{array}$ & $\begin{array}{c}(3) \\
\text { PPML(T>0) }\end{array}$ & $\begin{array}{c}(4) \\
\text { PPML(T>0) }\end{array}$ & $\begin{array}{c}(5) \\
\text { PPML }\end{array}$ & $\begin{array}{c}(6) \\
\text { PPML }\end{array}$ & $\begin{array}{c}(7) \\
\text { TOBIT }\end{array}$ & $\begin{array}{c}(8) \\
\text { TOBIT }\end{array}$ \\
\hline Dependent Variable & $\begin{array}{l}\text { Log of } \\
\text { Imports } \\
\end{array}$ & $\begin{array}{l}\text { Log of } \\
\text { Imports } \\
\end{array}$ & Imports & Imports & Imports & Imports & Imports & Imports \\
\hline Log of GDP partner & $\begin{array}{c}0.209^{* * *} \\
(14.49)\end{array}$ & $\begin{array}{c}0.225^{* * * *} \\
(15.08)\end{array}$ & $\begin{array}{c}0.196^{* * * *} \\
(3.58)\end{array}$ & $\begin{array}{c}0.288^{* * * *} \\
(8.83)\end{array}$ & $\begin{array}{c}0.809 * * * \\
(11.80)\end{array}$ & $\begin{array}{c}0.878^{* * * *} \\
(23.60)\end{array}$ & $\begin{array}{c}0.076 * * * \\
(4.72)\end{array}$ & $\begin{array}{c}0.061 * * * \\
(4.32)\end{array}$ \\
\hline $\begin{array}{l}\text { Log of GDPPC } \\
\text { partner }\end{array}$ & $\begin{array}{l}0.0411 \\
(1.31)\end{array}$ & $\begin{array}{l}0.0353 \\
(1.03)\end{array}$ & $\begin{array}{c}0.215^{* * * *} \\
(3.39)\end{array}$ & $\begin{array}{c}0.198 * * * \\
(3.49)\end{array}$ & $\begin{array}{c}0.341^{* * *} * \\
(3.87)\end{array}$ & $\begin{array}{c}0.314 * * * \\
(3.92)\end{array}$ & $\begin{array}{c}0.016 * * * \\
(2.67)\end{array}$ & $\begin{array}{c}0.013 * * * \\
(2.63)\end{array}$ \\
\hline Log of distance & $\begin{array}{c}-0.240 * * * \\
(-4.98)\end{array}$ & $\begin{array}{c}-0.247 * * * \\
(-5.07)\end{array}$ & $\begin{array}{c}-0.307 * * \\
(-2.58)\end{array}$ & $\begin{array}{c}-0.323^{* *} \\
(-2.75)\end{array}$ & $\begin{array}{c}-0.966^{* * * *} \\
(-6.81)\end{array}$ & $\begin{array}{c}-1.017 * * * \\
(-7.69)\end{array}$ & $\begin{array}{c}-0.076^{* * * *} \\
(-4.07)\end{array}$ & $\begin{array}{c}-0.060 * * * \\
(-3.83)\end{array}$ \\
\hline Colonial relationship & $\begin{array}{l}0.125 \\
(0.73)\end{array}$ & $\begin{array}{l}0.163 \\
(0.90)\end{array}$ & $\begin{array}{l}0.473 \\
(1.12)\end{array}$ & $\begin{array}{l}0.636 \\
(1.38)\end{array}$ & $\begin{array}{c}0.944 * * \\
(2.33)\end{array}$ & $\begin{array}{c}1.167 * * * \\
(2.68)\end{array}$ & $\begin{array}{c}0.069 * * \\
(2.19)\end{array}$ & $\begin{array}{c}0.059 * * \\
(2.30)\end{array}$ \\
\hline
\end{tabular}


Yönetim ve Ekonomi Araștırmaları Dergisi / Journal of Management and Economics Research Cilt/Volume: 15 Sayı/Issue: Özel Sayı 1/Special Issue 1 Aralık/December 2017 ss./pp. 188-211 Ö. Bilici Doi: http://dx.doi.org/10.11611/yead.373458

\begin{tabular}{|c|c|c|c|c|c|c|c|c|}
\hline Common legislation & $\begin{array}{r}0.0347 \\
(0.22)\end{array}$ & $\begin{array}{l}-0.0292 \\
(-0.18)\end{array}$ & $\begin{array}{c}0.0714 \\
(0.22)\end{array}$ & $\begin{array}{c}0.0182 \\
(0.05)\end{array}$ & $\begin{array}{l}0.475 \\
(1.37)\end{array}$ & $\begin{array}{l}0.371 \\
(1.05)\end{array}$ & $\begin{array}{c}0.051^{*} \\
(1.70)\end{array}$ & $\begin{array}{l}0.037 \\
(1.60)\end{array}$ \\
\hline Common language & $\begin{array}{c}-0.00300 \\
(-0.03)\end{array}$ & $\begin{array}{c}-0.00677 \\
(-0.07)\end{array}$ & $\begin{array}{c}-0.0561 \\
(-0.24)\end{array}$ & $\begin{array}{l}-0.130 \\
(-0.62)\end{array}$ & $\begin{array}{l}-0.166 \\
(-0.65)\end{array}$ & $\begin{array}{l}-0.276 \\
(-1.28)\end{array}$ & $\begin{array}{l}0.009 \\
(0.56)\end{array}$ & $\begin{array}{l}0.006 \\
(0.43)\end{array}$ \\
\hline Time difference & $\begin{array}{c}-0.00417 \\
(-0.17)\end{array}$ & $\begin{array}{c}-0.0109 \\
(-0.44)\end{array}$ & $\begin{array}{c}-0.00482 \\
(-0.08)\end{array}$ & $\begin{array}{l}-0.0592 \\
(-1.15)\end{array}$ & $\begin{array}{l}0.112^{*} \\
(1.66)\end{array}$ & $\begin{array}{l}0.0696 \\
(1.16)\end{array}$ & $\begin{array}{c}0.076^{*} \\
(1.92)\end{array}$ & $\begin{array}{l}0.006^{*} \\
(1.82)\end{array}$ \\
\hline \multirow{2}{*}{$\begin{array}{l}\text { Regional trade } \\
\text { agreement }\end{array}$} & -0.144 & $-0.219^{*}$ & -0.150 & -0.259 & 0.540 & 0.418 & 0.042 & 0.033 \\
\hline & $(-1.00)$ & $(-1.57)$ & $(-0.55)$ & $(-1.03)$ & $(1.33)$ & $(1.05)$ & $(1.33)$ & (1.29) \\
\hline GATT membership & $\begin{array}{l}-0.0285 \\
(-0.14)\end{array}$ & $\begin{array}{c}0.00939 \\
(0.05)\end{array}$ & $\begin{array}{l}-0.0636 \\
(-0.16)\end{array}$ & $\begin{array}{l}-0.165 \\
(-0.45)\end{array}$ & $\begin{array}{l}0.433 \\
(1.29)\end{array}$ & $\begin{array}{l}0.408 \\
(1.13)\end{array}$ & $\begin{array}{c}0.043 * * * \\
(2.80)\end{array}$ & $\begin{array}{c}0.032 * * \\
(2.58)\end{array}$ \\
\hline \multirow{2}{*}{$\begin{array}{l}\text { European Union } \\
\text { membership }\end{array}$} & -0.229 & -0.203 & -0.226 & -0.194 & -0.229 & -0.286 & 0.019 & 0.017 \\
\hline & $(-1.59)$ & $(-1.23)$ & $(-1.15)$ & $(-1.05)$ & $(-0.60)$ & $(-0.80)$ & $(0.73)$ & $(0.77)$ \\
\hline \multirow{2}{*}{$\begin{array}{l}\text { Log of \# of } \\
\text { employees }\end{array}$} & & $0.179 * * *$ & & $0.387 * * *$ & & $0.607^{* * *}$ & & $0.025 * * *$ \\
\hline & & (11.08) & & $(12.65)$ & & (20.63) & & (4.16) \\
\hline \multirow{2}{*}{$\begin{array}{l}\text { Log of labor } \\
\text { productivity }\end{array}$} & & $0.271 * * *$ & & $0.466^{* * * *}$ & & $0.772^{* * *}$ & & $0.035^{* * *}$ \\
\hline & & (14.89) & & $(14.96)$ & & $(22.22)$ & & $(4.28)$ \\
\hline Log of age of the firm & & $\begin{array}{c}-0.0230 \\
(-0.34)\end{array}$ & & $\begin{array}{c}-0.0341 \\
(-0.21)\end{array}$ & & $\begin{array}{l}-0.105 \\
(-0.77)\end{array}$ & & $\begin{array}{l}-0.002 \\
(-0.55)\end{array}$ \\
\hline \multirow{2}{*}{$\begin{array}{l}\text { Dummy for being an } \\
\text { LLC }\end{array}$} & & $0.883^{* * *}$ & & $1.451 * * *$ & & $1.064 * * *$ & & $-0.097 * * *$ \\
\hline & & (11.87) & & $(10.41)$ & & $(7.74)$ & & $(-3.86)$ \\
\hline$R \& D$ engagement & & $\begin{array}{c}-0.126^{* *} \\
(-2.50)\end{array}$ & & $\begin{array}{l}0.170 \\
(1.26)\end{array}$ & & $\begin{array}{c}0.535 * * \\
(3.17)\end{array}$ & & $\begin{array}{c}0.032 * * * \\
(2.82)\end{array}$ \\
\hline Constant & $\begin{array}{c}3.414 * * * \\
(6.57) \\
\end{array}$ & $\begin{array}{l}0.583 \\
(1.00) \\
\end{array}$ & $\begin{array}{c}4.678^{* * * *} \\
(3.80) \\
\end{array}$ & $\begin{array}{l}-1.119 \\
(-0.81) \\
\end{array}$ & $\begin{array}{l}-2.701 * \\
(-1.93) \\
\end{array}$ & $\begin{array}{c}-10.05 * * * \\
(-6.91)\end{array}$ & & \\
\hline $\mathrm{N}$ & 13,988 & 13,012 & 13,988 & 13,012 & $16,219,700$ & $15,528,800$ & $16,219,700$ & $15,528,800$ \\
\hline R-squared & 0.039 & 0.078 & 0.004 & 0.020 & 0.0002 & 0.001 & 0.089 & 0.096 \\
\hline RESET (p-values) & 0.0007 & 0.000 & 0.7460 & 0.1494 & 0.8098 & 0.4565 & 0.0024 & 0.0398 \\
\hline
\end{tabular}

The dependent variable is the value of service imports incurred by each firm. The log of imports is used in OLS estimations. t-statistics (from OLS) and z-statistics (from PPML and Tobit) in parentheses are calculated based on country clustered robust standard errors. Pseudo R-squared in Tobit regressions. p-values of RESET test for the model in each column is provided in the last row. Column 7 and 8 provide the marginal effects (marginal effects on $\mathrm{E}(\mathrm{y} \mid \mathrm{X}))$ from Tobit regressions. * Significant at the $10 \%$ level, ** Significant at the 5\% level, *** Significant at the $1 \%$ level.

Table 5: Firm-level Imports Analyses with Firm-by-service Type Fixed Effects

\begin{tabular}{|c|c|c|c|c|c|c|}
\hline & $\begin{array}{c}(1) \\
\text { FE w/o } \\
\text { firm } \\
\text { variables }\end{array}$ & $\begin{array}{c}\text { (2) } \\
\text { FE w/ firm } \\
\text { variables }\end{array}$ & $\begin{array}{c}3) \\
\text { Poisson }(\mathrm{T}>0) \\
\text { w/o firm } \\
\text { variables }\end{array}$ & $\begin{array}{c}(4) \\
\text { Poisson }(\mathrm{T}>0) \\
\text { w/ firm } \\
\text { variables }\end{array}$ & $\begin{array}{c}(5) \\
\text { Poisson w/o } \\
\text { firm } \\
\text { variables }\end{array}$ & $\begin{array}{c}\text { (6) } \\
\text { Poisson w/ } \\
\text { firm } \\
\text { variables }\end{array}$ \\
\hline Dependent Variable & $\begin{array}{c}\text { Log of } \\
\text { Imports }\end{array}$ & $\begin{array}{l}\text { Log of } \\
\text { Imports }\end{array}$ & Imports & Imports & Imports & Imports \\
\hline Log of GDP partner & $\begin{array}{c}0.290 * * * \\
(15.84)\end{array}$ & $\begin{array}{c}0.290 * * * \\
(14.78)\end{array}$ & $\begin{array}{c}0.375 * * * \\
(2.73)\end{array}$ & $\begin{array}{c}0.482 * * * \\
(4.41)\end{array}$ & $\begin{array}{c}0.809 * * * \\
(12.42)\end{array}$ & $\begin{array}{c}0.878 * * * \\
(21.20)\end{array}$ \\
\hline Log of GDPPC partner & $\begin{array}{c}0.0343 \\
(1.42)\end{array}$ & $\begin{array}{c}0.0361 \\
(1.44)\end{array}$ & $\begin{array}{c}0.268 * * * \\
(3.05)\end{array}$ & $\begin{array}{c}0.216^{* *} \\
(2.50)\end{array}$ & $\begin{array}{c}0.341 * * * \\
(5.35)\end{array}$ & $\begin{array}{c}0.314 * * * \\
(5.43)\end{array}$ \\
\hline Log of distance & $\begin{array}{c}-0.208 * * * \\
(-5.39)\end{array}$ & $\begin{array}{c}-0.203^{* * *} \\
(-5.01)\end{array}$ & $\begin{array}{c}-0.464 * * * \\
(-3.41)\end{array}$ & $\begin{array}{c}-0.519 * * * \\
(-3.55)\end{array}$ & $\begin{array}{c}-0.966 * * * \\
(-6.34)\end{array}$ & $\begin{array}{c}-1.017 * * * \\
(-6.18)\end{array}$ \\
\hline Colonial relationship & $0.319 * * *$ & $0.398 * * *$ & $0.708 *$ & $0.879 * *$ & $0.944 * * *$ & $1.167 * * *$ \\
\hline
\end{tabular}


Yönetim ve Ekonomi Araștırmaları Dergisi / Journal of Management and Economics Research Cilt/Volume: 15 Sayı/Issue: Özel Sayı 1/Special Issue 1 Aralık/December 2017 ss./pp. 188-211 Ö. Bilici Doi: http://dx.doi.org/10.11611/yead.373458

\begin{tabular}{|c|c|c|c|c|c|c|}
\hline & $(2.80)$ & $(3.48)$ & $(1.80)$ & $(2.13)$ & $(2.65)$ & $(2.88)$ \\
\hline Common legislation & $\begin{array}{c}0.177 * \\
(1.65)\end{array}$ & $\begin{array}{l}0.111 \\
(1.06)\end{array}$ & $\begin{array}{l}0.283 \\
(1.29)\end{array}$ & $\begin{array}{l}0.231 \\
(1.01)\end{array}$ & $\begin{array}{c}0.475 * * * \\
(3.05)\end{array}$ & $\begin{array}{c}0.371 * * \\
(2.42)\end{array}$ \\
\hline Common language & $\begin{array}{c}0.00344 \\
(0.05)\end{array}$ & $\begin{array}{c}-0.0326 \\
(-0.43)\end{array}$ & $\begin{array}{c}-0.0564 \\
(-0.25)\end{array}$ & $\begin{array}{l}-0.107 \\
(-0.47)\end{array}$ & $\begin{array}{l}-0.166 \\
(-0.62)\end{array}$ & $\begin{array}{l}-0.276 \\
(-0.86)\end{array}$ \\
\hline Time difference & $\begin{array}{c}-0.00562 \\
(-0.38)\end{array}$ & $\begin{array}{c}-0.00890 \\
(-0.56)\end{array}$ & $\begin{array}{c}0.0176 \\
(0.31)\end{array}$ & $\begin{array}{c}-0.0328 \\
(-0.77)\end{array}$ & $\begin{array}{c}0.112 * * \\
(2.24)\end{array}$ & $\begin{array}{l}0.0696 \\
(1.63)\end{array}$ \\
\hline \multirow{2}{*}{$\begin{array}{l}\text { Regional trade } \\
\text { agreement }\end{array}$} & 0.00832 & -0.0118 & -0.0356 & -0.125 & $0.540 * * *$ & $0.418 * * *$ \\
\hline & $(0.10)$ & $(-0.13)$ & $(-0.17)$ & $(-0.65)$ & $(4.02)$ & $(3.07)$ \\
\hline GATT membership & $\begin{array}{c}-0.272 * * \\
(-2.55)\end{array}$ & $\begin{array}{c}-0.249 * * \\
(-2.24)\end{array}$ & $\begin{array}{l}-0.474 \\
(-1.53)\end{array}$ & $\begin{array}{l}-0.471 \\
(-1.54)\end{array}$ & $\begin{array}{l}0.433 * \\
(1.85)\end{array}$ & $\begin{array}{l}0.408 * \\
(1.87)\end{array}$ \\
\hline EU membership & $\begin{array}{c}-0.0904 \\
(-1.49)\end{array}$ & $\begin{array}{c}-0.0797 \\
(-1.27)\end{array}$ & $\begin{array}{l}-0.182 \\
(-0.75)\end{array}$ & $\begin{array}{l}-0.302 \\
(-1.53)\end{array}$ & $\begin{array}{l}-0.229 \\
(-1.23)\end{array}$ & $\begin{array}{l}-0.286 \\
(-1.63)\end{array}$ \\
\hline $\mathrm{N}$ & 13,988 & 13,012 & 10,879 & 10,067 & 884,275 & 832,475 \\
\hline RESET (p-values) & 0.0529 & 0.1238 & 0.8904 & 0.3728 & 0.6762 & 0.4605 \\
\hline
\end{tabular}

In order to produce these results, a panel dataset is created based countries and panel ids that are generated by grouping each firm by each service type then firm-by-service type FE included in all models. The dependent variable is the value of service imports incurred by each firm. The log of imports is used in OLS estimations. tstatistics (from OLS) and z-statistics (from PPML) in parentheses are calculated based on heteroskedasticity robust standard errors. p-values of RESET test for the model in each column is provided in the last row. * Significant at the $10 \%$ level, $* *$ Significant at the $5 \%$ level, $* * *$ Significant at the $1 \%$ level.

Table 6: Aggregate Exports and Imports

\begin{tabular}{|c|c|c|c|c|c|c|c|c|}
\hline & \multicolumn{4}{|c|}{ Export } & \multicolumn{4}{|c|}{ Import } \\
\hline & (1) & (2) & (3) & (4) & (5) & (5) & (5) & (8) \\
\hline & OLS & OLS & PPML & PPML & OLS & OLS & PPML & PPML \\
\hline Log of GDP partner & $\begin{array}{c}0.989 * * * \\
(16.10)\end{array}$ & $\begin{array}{c}0.936 * * * \\
(16.84)\end{array}$ & $\begin{array}{c}0.612 * * * \\
(14.78)\end{array}$ & $\begin{array}{c}0.607 * * * \\
(12.74)\end{array}$ & $\begin{array}{c}1.045^{* * *} \\
(20.10)\end{array}$ & $\begin{array}{c}0.961 * * * \\
(19.06)\end{array}$ & $\begin{array}{c}0.808 * * * \\
(11.78)\end{array}$ & $\begin{array}{c}0.773 * * * \\
(9.40)\end{array}$ \\
\hline \multirow{2}{*}{$\begin{array}{l}\text { Log of GDPPC } \\
\text { partner }\end{array}$} & $0.397 * * *$ & $0.260^{* *}$ & $0.516^{* * *}$ & $0.512 * * *$ & 0.143 & 0.0285 & $0.340 * * *$ & $0.338 * * *$ \\
\hline & $(3.80)$ & $(2.20)$ & $(3.62)$ & $(3.78)$ & $(1.62)$ & $(0.33)$ & $(3.87)$ & $(4.14)$ \\
\hline \multirow[t]{2}{*}{ Log of distance } & 0.0576 & -0.0509 & - & - & - & - & - & - \\
\hline & $(0.17)$ & $(-0.17)$ & $\begin{array}{c}0.569 * * * \\
(-2.75)\end{array}$ & $\begin{array}{c}0.614 * * * \\
(-3.03)\end{array}$ & $\begin{array}{c}0.848 * * * * \\
(-3.08)\end{array}$ & $\begin{array}{c}0.845^{* * * *} \\
(-3.20)\end{array}$ & $\begin{array}{c}0.968 * * * * \\
(-6.82)\end{array}$ & $\begin{array}{c}0.939 * * * \\
(-7.26)\end{array}$ \\
\hline \multirow{2}{*}{$\begin{array}{l}\text { Colonial } \\
\text { relationship }\end{array}$} & $0.641 * *$ & 0.346 & -0.351 & -0.414 & $0.793 *$ & 0.365 & $0.941 * *$ & $1.023 * *$ \\
\hline & $(2.40)$ & (1.19) & $(-1.16)$ & $(-1.54)$ & $(1.91)$ & $(0.78)$ & $(2.13)$ & $(2.42)$ \\
\hline \multirow{2}{*}{$\begin{array}{l}\text { Common } \\
\text { legislation }\end{array}$} & 0.381 & 0.354 & $0.740 * * *$ & $0.744 * * *$ & $0.925^{* *}$ & $0.797 *$ & 0.472 & 0.417 \\
\hline & $(1.47)$ & $(1.22)$ & $(3.50)$ & $(3.60)$ & (2.19) & $(1.81)$ & $(1.36)$ & $(1.28)$ \\
\hline Common language & $\begin{array}{c}0.737 * * * \\
(3.16)\end{array}$ & $\begin{array}{c}0.836 * * * \\
(4.06)\end{array}$ & $\begin{array}{c}0.862 * * * \\
(3.00)\end{array}$ & $\begin{array}{c}0.909 * * * \\
(3.90)\end{array}$ & $\begin{array}{l}0.542 \\
(1.50)\end{array}$ & $\begin{array}{c}0.605^{*} \\
(1.97)\end{array}$ & $\begin{array}{l}-0.163 \\
(-0.63)\end{array}$ & $\begin{array}{l}-0.250 \\
(-0.97)\end{array}$ \\
\hline \multirow[t]{2}{*}{ Time difference } & - & - & -0.0232 & 0.00368 & $-0.0906^{*}$ & -0.0789 & $0.112 *$ & $0.119^{*}$ \\
\hline & $\begin{array}{c}0.202 * * * \\
(-3.48)\end{array}$ & $\begin{array}{c}0.173 * * * \\
(-3.12)\end{array}$ & $(-0.38)$ & $(0.06)$ & $(-1.74)$ & $(-1.65)$ & (1.66) & (1.65) \\
\hline
\end{tabular}


Yönetim ve Ekonomi Araștırmaları Dergisi / Journal of Management and Economics Research Cilt/Volume: 15 Sayı/Issue: Özel Sayı 1/Special Issue 1 Aralık/December 2017 ss./pp. 188-211 Ö. Bilici Doi: http://dx.doi.org/10.11611/yead.373458

\begin{tabular}{|c|c|c|c|c|c|c|c|c|}
\hline \multirow{2}{*}{$\begin{array}{l}\text { Regional trade } \\
\text { agreement }\end{array}$} & 0.322 & 0.115 & 0.0466 & 0.0612 & 0.216 & -0.195 & 0.529 & 0.559 \\
\hline & $(0.88)$ & $(0.36)$ & $(0.13)$ & $(0.17)$ & $(0.69)$ & $(-0.64)$ & $(1.30)$ & $(1.39)$ \\
\hline \multirow[t]{2}{*}{ GATT membership } & - & $-0.750 * *$ & $-0.901 * *$ & $-0.806 * *$ & -0.0300 & 0.0148 & 0.436 & $0.553^{*}$ \\
\hline & $\begin{array}{c}0.805 * * * \\
(-2.64)\end{array}$ & $(-2.54)$ & $(-2.39)$ & $(-2.20)$ & $(-0.08)$ & $(0.05)$ & $(1.30)$ & $(1.70)$ \\
\hline \multirow{2}{*}{$\begin{array}{l}\text { European Union } \\
\text { membership }\end{array}$} & 0.547 & $0.754 * *$ & -0.0704 & 0.0167 & 0.385 & $0.622 *$ & -0.229 & -0.256 \\
\hline & $(1.56)$ & (1.99) & $(-0.14)$ & $(0.03)$ & $(1.27)$ & $(1.75)$ & $(-0.60)$ & $(-0.73)$ \\
\hline \multirow{2}{*}{$\begin{array}{l}\text { Log of avg. labor } \\
\text { productivity }\end{array}$} & & $0.221 * * *$ & & 0.105 & & $0.192 * * *$ & & $-0.140 * *$ \\
\hline & & $(3.66)$ & & $(1.58)$ & & $(4.40)$ & & $(-2.16)$ \\
\hline \multirow{2}{*}{$\begin{array}{l}\text { Log of avg. \# of } \\
\text { employees }\end{array}$} & & $0.187 * *$ & & $-0.210^{* *}$ & & $0.360 * * *$ & & 0.0499 \\
\hline & & $(2.13)$ & & $(-2.06)$ & & $(3.21)$ & & $(0.27)$ \\
\hline Constant & $\begin{array}{l}1.642 \\
(0.58) \\
\end{array}$ & $\begin{array}{l}0.977 \\
(0.37) \\
\end{array}$ & $\begin{array}{c}7.895 * * * \\
(3.54) \\
\end{array}$ & $\begin{array}{c}8.652 * * * \\
(3.90) \\
\end{array}$ & $\begin{array}{c}8.754 * * * \\
(3.44) \\
\end{array}$ & $\begin{array}{c}6.588 * * * \\
(2.63) \\
\end{array}$ & $\begin{array}{c}8.783 * * * \\
(6.30) \\
\end{array}$ & $\begin{array}{c}9.394 * * * \\
(5.69) \\
\end{array}$ \\
\hline $\mathrm{N}$ & 171 & 170 & 171 & 170 & 165 & 161 & 165 & 161 \\
\hline R-squared & 0.804 & 0.830 & 0.918 & 0.924 & 0.813 & 0.850 & 0.981 & 0.982 \\
\hline RESET ( $p$ values) & 0.6821 & 0.1293 & 0.8360 & 0.6419 & 0.7951 & 0.1142 & 0.7567 & 0.7895 \\
\hline
\end{tabular}

The dependent variables are the total exports and imports in services. The log of dependent variable is used in OLS estimations. t-statistics (from OLS) and z-statistics (from PPML) in parentheses are calculated based on heteroskedasticity robust standard errors. p-values of RESET test for the model in each column is provided in the last row. * Significant at the $10 \%$ level, ** Significant at the $5 \%$ level, *** Significant at the $1 \%$ level 